\title{
Development and Quality Evaluation of Corn Based Extruded Snacks Incorporating Goat Offal Meat Powder
}

\author{
Brighton Jabez $^{1^{*}}$ and V. Nithyalakshmi ${ }^{2}$ \\ ${ }^{1}$ College of Food and Dairy Technology, Tamilnadu Veterinary and Animal Sciences \\ University, Koduveli, Chennai - 600 052, India \\ ${ }^{2}$ Department of Food Process Engineering, College of Food and Dairy Technology, \\ Tamilnadu veterinary and Animal Sciences University, Koduveli, Chennai - 600 052, India \\ *Corresponding author
}

\section{A B S T R A C T}

\begin{tabular}{|l|}
\hline Ke y w o r d s \\
Ready-to-eat \\
snacks, Extrusion, \\
Goat offal meat \\
powder
\end{tabular}

Ready-to-Eat (RTE) snackfood was developed using corn (Zea mays), rice (Oryza sativa), Bengal gram dal (Cicer arietinum) and Goat offal meat powder with a laboratory model twin screw extruder. The extrudates were developed by conducting various blends (corn + rice+ bengal gram dal flour) in the ratio of $\mathrm{T}_{1}(40: 40: 20), \mathrm{T}_{2}$ (50:40:10), $\mathrm{T}_{3}(60: 30: 10), \mathrm{T}_{4}$ (50:30:20), $\mathrm{T}_{5}$ (40:50:10) and incorporating Goat offal meat powder viz., $(1,3,5 \& 7 \%)$ levels. Among the different blends studied, $\mathrm{T}_{3}$ has been standardized base on the sensory evaluation scores. The incorporation level $3 \%$ of Goat offal meat powder has been standardized based on the proximate composition and acceptability studies by untrained panellists using a 9-point hedonic scale.

\section{Introduction}

Goat offal meat is a good source of various macro and micro nutrients with higher biological values. As health is concerned, for the various metabolic and physiologic activity of body, body needs macro and micro nutrients like protein, fat, fibre, vitamins such as Vitamin $B_{12}$, minerals such as zinc, cobalt, calcium, etc. The incorporation or addition of offal meat as a nutrient source will improvise the nutrition content of the food products. Incorporating goat offal meat in the corn based snack food will be a better selection so that the nutrients of offal meat will reach most of the snack food consumers.

Extruded RTE snack foods are mostly of cereal based with a limitation of poor content of protein, since cereals are predominant source of carbohydrates (Iqbal et al., 2006). Incorporation of protein source into cereal based extruded snacks would not only rectify its nutritional inadequacies, but also provides a variety of food and food products. Many attempts have been made in the food science 
field in developing a protein rich RTE snacks with incorporation of fish powder (Catla catla, Sardinella longiceps and Saurida tumbil), foxtail millet, shrimp powder (Parapenaeopsis stylifera). (Kuna, 2013; Ganesan et al., 2017; (Geeta, 2016; Shaviklo, 2015).

There are various reports on extruded products made from blends of meat and cereal ingredients (Lee et al., 2003; Mittal and Lawrie, 1984). Rhee et al., (1999) studied mixtures of maize flour and minced meat from hen, mutton, lamb and beef using a singlescrew extruder. However, extrusion of starch rich ingredients blended with animal proteins is problematic due to the unstable thermal characteristics of the formulation (Yurjew et al., 1989). The suitability of selected meat for snack food manufactured by indirect extrusion cooking has been evaluated. The results indicated that lean meat showed better extrusion characteristics than that of fatty meat while fresh meat being superior to frozen meat. Washing of the animal meat was found to enhance meat utility in extrusion cooking (Wianecki, 2007). The incorporation of animal proteins to starch-rich ingredients such as rice flour significantly reduced expansion and increased hardness. This could be the reason why attempts to develop expanded snack food products from blends of meat powder and starchy ingredients using extruder have met with limited success (Choudhury and Gautam, 2003).

The extrusion of puffed snacks is very sensitive to variations in feed composition, extrusion temperature, barrel screw speed and extruder type. Although the addition of meat protein to blends intended for extrusion is limited by technological constraints, it is highly desirable to develop such products from a nutritional point of view (Wianecki, 2007). The present study was carried out to develop an extruded puffed snack from goat offal meat, to optimize the offal meat content of the puffed snack based on the sensory and protein characteristics of the developed snack.

\section{Materials and Methods}

\section{Materials}

The goat offal meat was procured from local goat meat market in Chennai. Corn flour, rice flour, gram flour and salt were purchased from local market in Chennai. All the reagents used for the chemical analysis of the products were of analytical grade.

\section{Methods}

\section{Preparation of offal meat powder (OMP)}

Goat offal meat was prepared as powder for the preparation of offal meat powder extruded snacks. Goat offal such as omasum, abomasums, rumen and rectum of sound quality was purchased from the local butcher and brought to the processing hall for further processing. The cleaned goat offal meat was cooked by using cookware 15-20 minutes. The cooked meat were placed in food grade SS trays and dried in a tray drier at $65^{\circ} \mathrm{C}$ for $20 \mathrm{hrs}$. The dried offal meat was powdered in a domestic mixer grinder at the rate of $100 \mathrm{~g} / 2$ minutes.

\section{Formulation and Extrusion processing}

Ingredients such as corn flour, rice flour, gram flour, pepper and salt of good quality were procured from the local market for the conduct of experiment. About 5 numbers of trials $\left(\mathrm{T}_{1}\right.$, $\mathrm{T}_{2}, \mathrm{~T}_{3}, \mathrm{~T}_{4}, \mathrm{~T}_{5}$ ) were conducted to standardize the base of the product with various combinations of the ingredients (Table 1). The base ingredients were standardized with the trials conducted and Trial $\left(\mathrm{T}_{3}\right)$ combination is found to be highly acceptable and optimum for effective processing. 
Incorporation level of OMP has been standardized, by conducting trials of various levels $(1 \%, 3 \%, 5 \%$ and $7 \%)$ of OMP with the following proportions of flour mix $\left(\mathrm{T}_{3}\right)$ as described in Table 1 with the addition of pepper $(2 \%)$ as seasoning. The extrudates obtained with all the four levels of incorporation of OMP is compared with the control for the physico-chemical parameters and sensory evaluations.

\section{Extrusion cooking}

The twin-screw extruder of $15 \mathrm{~kg} / \mathrm{h}$ capacity was used for the preparation of OMP based extruded snacks. The extruder was turned on and the heating sections Heater $1 \& 2$ were set at $65^{\circ} \mathrm{C}$ and $120^{\circ} \mathrm{C}$ respectively. Once the necessary temperature has reached, the preconditioned flour mixture was fed into feed hopper equipped with screw augers to load materials into the barrel at a uniform rate (10 $\mathrm{kg} / \mathrm{h}$ ).

The barrel screw speed was kept constant at $350 \mathrm{rpm}$ respectively. The plasticized mass was passed through $3 \mathrm{~mm}$ die and exposed to the atmosphere, which led to the expansion of the extruded product. As the material was extruded, it was cut into pieces of the desired length by adjusting the rotating speed of cutter blade.

The OMP incorporation level 3\% has been standardized based on the physico-chemical and sensory evaluation results (Table 2 and 3 ). The processing flow chart is given in (Fig. 1).

\section{Proximate composition}

The proximate composition was determined according to (AOAC, 1995) methods. Crude protein content was determined using the Kjeldahl method. Ether extract was determined by the Soxhlet method. Ash content was determined by heating samples overnight $(24 \mathrm{hrs})$ at $550^{\circ} \mathrm{C}$. Moisture content was determined by drying samples for $4 \mathrm{~h}$ at $105^{\circ} \mathrm{C}$ until constant weight was achieved. Carbohydrate content was calculated by difference method.

\section{Sensory evaluation}

Sensory evaluation of control and OMP based extruded snacks were made by untrained panellists at College of Food and Dairy Technology, Chennai.

The sensory data (Table 3) to describe the intensity of each attribute for the given samples was prepared by the panel. Average scores of the judges were calculated for each sample assessed and the reported values were the average of duplicate samples.

\section{Results and Discussion}

The incorporation of OMP improves the nutritional content of the snack product (Table 3). When compared with control sample (13.18 \pm 0.14$), 1 \%$ OMP enrichment shows (14.21 \pm 0.18$), 3 \%$ OMP enrichment shows (15.13 \pm 0.17$), 5 \%$ OMP enrichment shows $(16.57 \pm 0.11)$ and $7 \%$ enrichment contributes $(19.19 \pm 0.16)$ in the protein levels.

Therefore addition of OMP increases the protein content of end product. Protein, fat, ash values are increasing significantly $(\mathrm{P}<0.01)$ due to the proportion of addition of offal meat powder.

Ether extract values contribute $(0.36 \pm 0.04$, $0.47 \pm 0.03,0.55 \pm 0.04,0.58 \pm 0.06,0.62 \pm 0.04)$ for control and 1, 3, 5, 7\% of OMP level enriched snacks. There will be small levels of elevation in the crude fibre levels in all the control and OMP enriched samples. The carbohydrate levels were considerably decreased in all the subsequent levels of OMP enriched snacks. 
Table.1 Formulation of control sample with various combinations of ingredients

\begin{tabular}{|l|c|c|c|c|c|}
\hline \multicolumn{1}{|c|}{ Ingredients (\%) } & $\mathbf{T}_{\mathbf{1}}$ & $\mathbf{T}_{\mathbf{2}}$ & $\mathbf{T}_{\mathbf{3}}$ & $\mathbf{T}_{\mathbf{4}}$ & $\mathbf{T}_{\mathbf{5}}$ \\
\hline Corn & 40 & 50 & 60 & 50 & 40 \\
\hline Rice & 40 & 40 & 30 & 30 & 50 \\
\hline Bengal gram flour & 20 & 10 & 10 & 20 & 10 \\
\hline Moisture (ml) & 10 & 10 & 10 & 10 & 10 \\
\hline Salt & 3 & 3 & 3 & 3 & 3 \\
\hline
\end{tabular}

Table.2 Physico-chemical properties of the OMP incorporated extruded snacks

\begin{tabular}{|l|c|c|c|c|c|c|}
\hline \multicolumn{1}{|c|}{ Parameters } & Control & 1\% OMP & 3\% OMP & 5\% OMP & 7\% OMP & F value \\
\hline Protein & $13.18^{\mathrm{a}} \pm 0.14$ & $14.21^{\mathrm{b}} \pm 0.18$ & $15.13^{\mathrm{c}} \pm 0.17$ & $16.57^{\mathrm{d}} \pm 0.11$ & $19.19^{\mathrm{e}} \pm 0.16$ & $858.070^{* *}$ \\
\hline Ether extract & $0.36^{\mathrm{a}} \pm 0.04$ & $0.47^{\mathrm{b}} \pm 0.03$ & $0.55^{\mathrm{c}} \pm 0.04$ & $0.58^{\mathrm{c}} \pm 0.06$ & $0.62^{\mathrm{d}} \pm 0.04$ & $458.87^{* *}$ \\
\hline Crude Fibre & $0.64^{\mathrm{d}} \pm 0.004$ & $0.60^{\mathrm{c}} \pm 0.005$ & $0.51^{\mathrm{b}} \pm 0.004$ & $0.48^{\mathrm{a}} \pm 0.003$ & $0.47^{\mathrm{a}} \pm 0.004$ & $284.91^{* *}$ \\
\hline Ash & $1.20^{\mathrm{a}} \pm 0.05$ & $1.44^{\mathrm{b}} \pm 0.09$ & $1.67^{\mathrm{c}} \pm 0.05$ & $1.88^{\mathrm{d}} \pm 0.04$ & $1.89^{\mathrm{d}} \pm 0.07$ & $178.86^{* *}$ \\
\hline Moisture & $5.23^{\mathrm{a}} \pm 0.06$ & $4.10^{\mathrm{b}} \pm 0.03$ & $4.19^{\mathrm{c}} \pm 0.06$ & $4.24^{\mathrm{d}} \pm 0.07$ & $4.18^{\mathrm{c}} \pm 0.03$ & $1191.36^{* *}$ \\
\hline Carbohydrate & $79.39^{\mathrm{d}} \pm 0.12$ & $79.18^{\mathrm{d}} \pm 0.14$ & $77.95^{\mathrm{c}} \pm 0.11$ & $76.25^{\mathrm{b}} \pm 0.17$ & $73.65^{\mathrm{a}} \pm 0.15$ & $327.23^{* *}$ \\
\hline
\end{tabular}

Table.3 Sensory properties of the OMP incorporated extruded snacks

\begin{tabular}{|l|c|c|c|c|c|c|}
\hline Parameters & Control & $\mathbf{1 \%}$ & $\mathbf{3 \%}$ & $\mathbf{5 \%}$ & $\mathbf{7 \%}$ & F value \\
\hline Color & $8.17 \pm 0.30$ & $8.23 \pm 0.30$ & $8.50 \pm 0.22$ & $7.83 \pm 0.30$ & $6.83 \pm 0.30$ & 4.5 \\
\hline Appearance & $8.43 \pm 0.30$ & $8.17 \pm 0.30$ & $8.00 \pm 0.25$ & $7.17 \pm 0.30$ & $7.17 \pm 0.30$ & 2.5 \\
\hline Flavor & $8.67 \pm 0.21$ & $8.67 \pm 0.21$ & $8.30 \pm 0.22$ & $6.83 \pm 0.30$ & $6.17 \pm 0.47$ & $15.1 * *$ \\
\hline Crispiness & $8.33 \pm 0.21$ & $8.43 \pm 0.21$ & $8.40 \pm 0.22$ & $7.83 \pm 0.30$ & $6.50 \pm 0.22$ & $11.9 * *$ \\
\hline Texture & $8.47 \pm 0.30$ & $8.17 \pm 0.30$ & $8.00 \pm 0.25$ & $6.83 \pm 0.30$ & $6.17 \pm 0.47$ & $7.2 * *$ \\
\hline Overall acceptability & $8.35 \pm 0.30$ & $8.09 \pm 0.33$ & $8.30 \pm 0.25$ & $7.83 \pm 0.30$ & $6.83 \pm 0.30$ & $3.7 *$ \\
\hline
\end{tabular}

Fig.1 Flow chart of extrusion processing of goat offal meat enriched snack

Flour mix

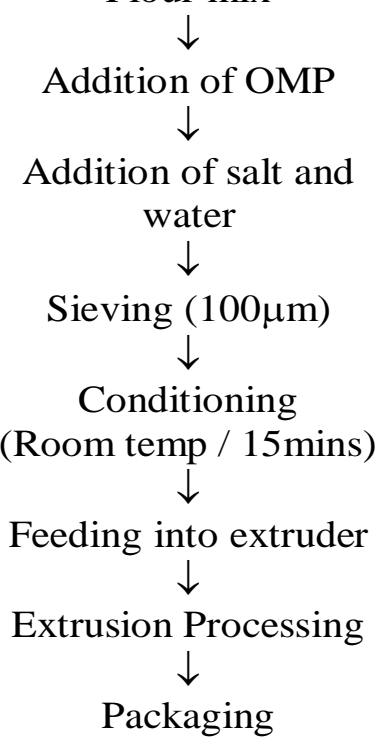


The sensory property (Table 3 ) concludes that the product with $1 \%$ and $3 \%$ enrichment of OMP in snacks attains good overall acceptability than the $5 \%$ and $7 \%$ enrichment levels. Thus compared with $1 \%$ level of OMP enrichment, the snack product incorporated with 3\% OMP attains the maximum sensory score with a higher protein enrichment levels when compared with the control sample. Therefore 3\% OMP enrichment level is optimum for the preparation of offal meat powder enriched extrude snacks.

Optimum incorporation of 3\% OMP was standardized in the study. Incorporation of OMP in the corn based extruded snacks shall deprive the protein malnutrition among the consumers. Protein supplement through snack foods could reach the children since now-a-days children are more attractive towards corn based extruded snacks.

The incorporation of OMP also imparts meat flavour which gives the consumer consuming a meat meal. Hence the objective of protein enrichment in corn based snack foods could be achieved by the incorporation of $3 \%$ of offal meat powder.

\section{References}

AOAC, 1995. Official Methods of Analysis, $16^{\text {th }}$ (ed.), Association of Official Analytical Chemists, Washington DC, USA.

Aparna Kuna N., Lakshmi Devi and Kalpana K. 2013. Utilization of Fish Powder in Readyto-Eat Extruded Snacks. Fishery Technology (50): 245 - 250.

Choudhury, G. S. and Gautam, A. (2003). Effects of hydrolysed fish muscle on intermediate process variables during twin-screw extrusion of rice flour. $L W T$ - Food Science and Technology, 36(7), 667-678.

Ganesan P., Rathnakumar K., Brita Nicy A. and Vijayarahavan V., (2017). Improvement of nutritional value of extruded snack product by incorporation of blanched dried fish powder from sardine and Lizard fish and selection by organoleptic evaluation. Journal of Entomology and Zoology Studies. 5(6): 2552-2554

Geeta H.P., Mathad P.F., Udaykumar Nidoni \& Ramachandra C.T., (2016). Development of foxtail millet based extruded food product. International Journal of Food Science and Technology. 6(2) 11-22.

Iqbal A., Khalil A., Ateeq N. and Khan M.S., (2007). Nutritional quality of important good legumes. Food Chemistry. 97: 331335

Lee S.O., Min J. S., Kim I. S., and Lee M. (2003). Physical evaluation of popped cereal snacks with spent hen meat. Meat science. 64(4), 383-390.

Mittal P. and Lawrie R.A. (1984). Extrusion studies of mixture containing certain meat offals. Part 1. Objective properties. Meat Science, 10: 101-116

Rhee K.S., Cho S.H. and Pradahn A.M. (1999). Composition, storage stability and sensory properties of expanded extrudates from blends of corn starch and goat meat, lamb, mutton, spent fowl meat, or beef. Meat Science, 52: 135-141.

Shaviklo A.R., Azaribeh M., Moradi Y. and Zangeneh P. (2015). Formula optimization and storage stability of extruded puffed corn-shrimp snacks. LWT-Food Science and Technology, 63 (1), 307-314

Wianecki M. (2007). Evaluation of fish and squid meat applicability for snack food manufacture by indirect extrusion cooking. Acta Scientiarum Polonorum: Technologia Alimentaria. P: 6

Yurjew V., Likhodziewskaya I., Zasypkin D., Alekseev V., Grinberg V. Y. and Polyakow V., (1989). Investigation of the microstructure of textured proteins produced by thermoplastic extrusion. Die Nahrung, 33, 823-830.

\section{How to cite this article:}

Brighton Jabez and Nithyalakshmi, V. 2019. Development and Quality Evaluation of Corn Based Extruded Snacks Incorporating Goat Offal Meat Powder. Int.J.Curr.Microbiol.App.Sci. 8(08): 19101914. doi: https://doi.org/10.20546/ijcmas.2019.808.224 